\title{
BOND STRENGTH DURABILITY OF SELF-ETCHING ADHESIVES AND RESIN CEMENTS TO DENTIN
}

\author{
Carolina de Andrade Lima CHAVES'1, Renata Marques de MELO², Sheila Pestana PASSOS², Fernanda Pelógia CAMARGO², \\ Marco Antonio BOTTINO ${ }^{3}$, Ivan BALDUCCI ${ }^{4}$
}

\author{
1- DDS, MSc, PhD Student, Dental School of Araraquara, São Paulo State University, Araraquara, SP, Brazil. \\ 2- DDS, MSc, PhD Student, Dental School of São José dos Campos, São Paulo State University, São José dos Campos, SP, Brazil. \\ 3- DDS, PhD, Chairman and Professor, Department of Dental Materials and Prosthodontics, Dental School of São José dos Campos, SP, Brazil. \\ 4- BSc, MSc, PhD, Professor, Department of Community Science and Pediatric Dentistry, Dental School of São José dos Campos, São Paulo State \\ University, São José dos Campos, SP, Brazil.
}

Corresponding address: Sheila Pestana Passos - Dental Materials and Prosthodontics Department - Av. Eng. Fco José Longo, 777 São José dos Campos, SP, Brasil - 12245-200 - Phone:+55 - 12-3947-9060 - e-mail: sheilapestana@hotmail.com

Received: March 27, 2008 - Modification: August 31, 2008 - Accepted: October 07, 2008

\begin{abstract}
O

bjectives: To evaluate the microtensile bond strength ( $\mu$ TBS) of one- (Xeno III, Dentsply) and two-step (Tyrian-One Step Plus, Bisco) self-etching adhesive systems bonded to dentin and cemented to chemically cured (C\&B Metabond) or light-cured paste of a dual-cure resin cement (Variolink II, Ivoclar) within a short ( $24 \mathrm{~h})$ and long period of evaluation ( 90 days). Material and Methods: Forty recently extracted human molars had their roots removed and their occlusal dentin exposed and ground wet with 600 -grit SiC paper. After application of one of the adhesives, the resin cement was applied to the bonded surface and a composite resin block was incrementally built up to a height of $5 \mathrm{~mm}(\mathrm{n}=10)$. The restored teeth were stored in distilled water at $37^{\circ} \mathrm{C}$ for 7 days. The teeth were then cut along two axes ( $\mathrm{x}$ and $\mathrm{y}$ ), producing beam-shaped specimens with $0.8 \mathrm{~mm}^{2}$ cross-sectional area, which were subjected to $\mu$ TBS testing at a crosshead speed of $0.05 \mathrm{~mm} / \mathrm{min}$ and stressed to failure after $24 \mathrm{~h}$ or 90 days of storage in water. The $\mu$ TBS data in MPa were subjected to three-way analysis of variance and Tukey's test $(\alpha=0.05)$. Results: The interaction effect for all three factors was statistically significant (three-way ANOVA, $\mathrm{p}<0.001)$. All eight experimental means $(\mathrm{MPa})$ were compared by the Tukey's test $(\mathrm{p}<0.05)$ and the following results were obtained: Tyrian-One Step Plus /C\&B/24 h (22.4 \pm 7.3$)$; Tyrian-One Step Plus /Variolink II/24 h (39.4 \pm 11.6$) ;$ Xeno III/C\&B/24 h (40.3 \pm 12.9$) ;$ Xeno III/Variolink II/24 h (25.8 \pm 10.5$)$; Tyrian-One Step Plus / C\&B/90 d (22.1 \pm 12.8$)$ Tyrian-One Step Plus/VariolinkII/90 d (24.2 \pm 14.2$) ;$ Xeno III/C\&B/90 d (27.0 \pm 13.5$)$; Xeno III/Variolink II/ $90 \mathrm{~d}(33.0 \pm 8.9)$. Conclusions: Xeno III/Variolink II was the luting agent/adhesive combination that provided the most promising bond strength after 90 days of storage in water.
\end{abstract}

Key words: Self-etching adhesives. Resin cements. Durability. Bond strength. Microtensile testing.

\section{INTRODUCTION}

Contemporary dentin adhesives are classified as threestep, two-step and one-step systems, depending on how the three cardinal steps of etching, priming, and bonding to tooth substrates are accomplished or simplified ${ }^{22,25}$. The reduction of steps has led to an increase in the complexity of these products and their interaction with restorative materials.

There is a trend to move towards adhesives that are more friendly to use. The two-step self-etching systems are userfriendly adhesives that mildly interact with the dentin substrate. One-step self-etching adhesives are more aggressive and, because of their highly acidic and hydrophilic nature, typically act as semipermeable membranes that attract water and degrade more quickly than hydrophobic adhesives ${ }^{6}$, causing loss of adhesion ${ }^{7}$. In addition to the problem of permeability of these adhesives, it is known that chemical composite resins containing tertiary amines as catalysts do not present good bond strength to most two-step total-etch adhesives and single-step self-etching systems. In these adhesives, the acidic monomers in the oxygen-inhibited layer are brought in direct contact with the chemically cured composite, titrating the basic amine accelerators and inactivating them ${ }^{5,10,20}$.

Resin luting agents are required for luting porcelain veneers, all-ceramic crowns, indirect composite or ceramic restorations, metal castings and endodontic posts. A strong and durable bond is necessary for the biomechanical aspect of the restorations when such cements are used ${ }^{4}$. Thus, appropriate treatment of the tooth substrate is also essential ${ }^{13}$. It is known that the chemical composition of the luting agent/ adhesive system influences bond strength to dental tissues ${ }^{5,15}$. Although dual-cure resin cements are the most used and studied formulations ${ }^{3,10}$, bonding durability studies using self- 
or light-cure agents have been scarcely addressed. Thus, the current study evaluated the short- and long-term bond strength of chemical and light-cure resin cements bonded to dentin with 2-step and one-step self-etching adhesives. Because the present study focused the interactions between the materials that may affect the strength at the adhesive interface over time, the following null hypotheses were tested:

(1) At 24-h storage, the bond strengths obtained with oneor two-step self-etching adhesives combined to chemically cured and light-cured cements are not different;

(2) At 90-day storage, the bond strengths obtained with one- or two-step self-etching adhesives combined to chemically cured and light-cured cements are not different;

(3) There are no differences in bonding durability between $24 \mathrm{~h}$ and 90 days of storage.

\section{MATERIAL AND METHODS}

Forty erupted human molars were extracted for periodontal reasons, cleaned with periodontal scales and stored in saline solution at $-4^{\circ} \mathrm{C}$. The teeth were obtained following the guidelines of the local Human Research Ethics Committee under the protocol number 087/2006-PH/CEP. The crowns were sectioned transversally with a diamond saw at low speed and copious water cooling to expose mid-coronal dentin. The roots were removed in the same manner at the cementoenamel junction. A standardized smear layer was created by wetgrounding the dentin surface with 600 -grit silicon carbide paper for $60 \mathrm{~s}$.

The teeth were divided into 4 groups of 10 teeth each, according to the adhesive system and the resin cement used: Tyrian SPE/One Step Plus two-step self-etching adhesive (Bisco, Inc., Schaumburg, IL, USA) + Variolink II resin cement (Ivoclar Vivadent, Schaan, Liechtenstein) dual cure resin cement that was used under light curing mode only (cement base); Tyrian SPE/One Step Plus adhesive system + C \& B Metabond chemical cure resin cement (Parkell Inc., Farmingdale, NY, USA); Xeno III one-step self-etching adhesive (Dentsply DeTrey, Konstanz, Germany) + Variolink II; Xeno III + C \& B Metabond.

The adhesives and resin cements were used according to the manufacturers' instructions (Table 1). After cement set, a composite resin (W3D; Wilcos do Brazil, Niterói, RJ, Brazil) block was incrementally built on cement surface up to a height of $5 \mathrm{~mm}$. Each increment of $2 \mathrm{~mm}$ was light-cured for $40 \mathrm{~s}$. All curing steps were performed with the same halogen lightcuring unit (Optilight Plus; Gnatus Equipamentos Médico-

TABLE 1- Tested materials

\begin{tabular}{|c|c|c|}
\hline $\begin{array}{l}\text { Materials } \\
\text { (Batch \#) }\end{array}$ & Application procedure & Composition \\
\hline $\begin{array}{c}\text { Tyrian SPE } \\
(02000104000)\end{array}$ & $\begin{array}{l}\text { 1. Apply primer Tyrian A + Tyrian B to } \\
\text { dentin with a microbrush and remove } \\
\text { excess with a microbrush after } 20 \mathrm{~s} \\
\text { 2. Apply two coats of adhesive One-Step }\end{array}$ & $\begin{array}{c}\text { Part A: Ethanol; Part B: 2-Acrylamide-2- } \\
\text { methyl propanesulfonic acid, } \\
\text { Bis (2-(methacryloyloxy)ethyl) phosphate, } \\
\text { Ethanol }\end{array}$ \\
\hline (02000104000) & $\begin{array}{l}\text { 3. Air-drying for } 10 \mathrm{~s} \\
\text { 4ight-curing for } 10 \mathrm{~s} \text { with the tip of the } \\
\text { light curing unit at } 5 \mathrm{~mm} \text { distance }\end{array}$ & $\begin{array}{l}\text { Biphenyl dimethacrylate, hydroxyethyl } \\
\text { methacrylate, acetone, glass }\end{array}$ \\
\hline $\begin{array}{c}\text { Xeno III } \\
(0411000228)\end{array}$ & $\begin{array}{l}\text { 1. Mix Universal liquid and Catalyst } \\
\text { 2. Apply mixture for } 20 \mathrm{~s} \\
\text { 3. Air drying; } \\
\text { 4. Light-cure for } 20 \mathrm{~s} \text { at a } 5 \mathrm{~mm} \text { distance. }\end{array}$ & $\begin{array}{l}\text { 2-Hydroxyethyl methacrylate, purified } \\
\text { water, ethanol, 2,6-Di-tertbutyl- } \\
\text { p hydroxy toluene, nanofiller }\end{array}$ \\
\hline $\begin{array}{l}\text { C\&B Metabond } \\
\text { (Polymer: } \\
\text { kV12; Catalyst: LF11) }\end{array}$ & $\begin{array}{l}\text { 1. Mix four drops of liquid (4-META) and } \\
\text { one drop of catalyst (TBB) with one scoop } \\
\text { of powder (PMMA) } \\
\text { 2. Apply the mixture to dentin and leave to } \\
\text { cure undisturbed (10-15 min). }\end{array}$ & $\begin{array}{l}\text { Base-Methyl Methacrylate monomer (4- } \\
\text { META), inhibited; } \\
\text { Powder-Polymethylmethacrylate; } \\
\text { Catalyst— tri-n-butylborane (TBB); } \\
\text { Hydrocarbon }\end{array}$ \\
\hline $\begin{array}{l}\text { Variolink II } \\
\text { (G26358) }\end{array}$ & $\begin{array}{l}\text { Place and light cure the base for } 40 \mathrm{~s} \text { from } \\
\text { each side }\end{array}$ & $\begin{array}{l}\text { Bisphenol-A-glycidyldimethacrylate, } \\
\text { Triethylene glycoldimethacrylate, } \\
\text { Urethanedimethacrylate, } \\
\text { inorganic fillers, ytterbiumtrifluoride, } \\
\text { initiators, stabilizers, pigments }\end{array}$ \\
\hline
\end{tabular}


Odontológicos Ltda, Ribeirão Preto, SP, Brazil) operating at $600 \mathrm{~mW} / \mathrm{cm}^{2}$.

The restored teeth were stored in distilled water at $37^{\circ} \mathrm{C}$ for 7 days and then cut along two axes ( $\mathrm{x}$ and $\mathrm{y}$ ) with a diamond disc under coolant irrigation. This process resulted in nontrimmed beam-shaped specimens with a cross-sectional area of approximately $0.8 \mathrm{~mm}^{2}$, as checked with a digital caliper). Each bonding group was then equally divided into two subgroups. In the first subgroup, the beams were stored in distilled water at $37^{\circ} \mathrm{C}$ for $24 \mathrm{~h}$. The second subgroup was stored in distilled water at $37^{\circ} \mathrm{C}$ for 90 days before testing. In this subgroup, the water was replaced on a weekly basis. Each beam was individually fixed to a custom-made testing jig with cyanoacrylate glue (Super Bonder Gel e Ativador 7456; Henkel Loctile Ltda., São Paulo, SP, Brazil). The device consisted of an adapted caliper meant to ensure that pure tensile forces were applied to the bond. The microtensile bond strength (mTBS) test $\left(0.5 \mathrm{~mm} . \mathrm{min}^{-1}\right.$ crosshead speed, $10 \mathrm{kgf}$ load cell) was performed in a universal testing machine (Emic
DL-1000; Emic, São José dos Pinhais, PR, Brazil).

The bond strength $\sigma(\mathrm{MPa})$ was calculated using the equation $\sigma=\mathrm{L} / \mathrm{A}$, where $\mathrm{L}$ is the load for failure of the specimen $(\mathrm{N})$ and $\mathrm{A}$ is the interfacial area $\left(\mathrm{mm}^{2}\right)$ (measured with a digital caliper before testing). The $\mu$ TBS means of the different groups were compared by using three-way analysis of variance and Tukey's multiple-comparison test at 5\% significance level. The number of beams stressed to failure is presented in Table 2. Statistical analysis was performed using Statistics 8.0 for Windows (Analytical Software Inc, Tallahassee, FL, USA). After $\mu$ TBS testing, some representative debonded dentin specimens were air-dried for $24 \mathrm{~h}$, sputter-coated with gold and observed with a scanning electron microscope (JEOLJSM-T330A; JEOL Ltda, Tokyo, Japan) to evaluate the fractured interfaces and determined the failure modes.

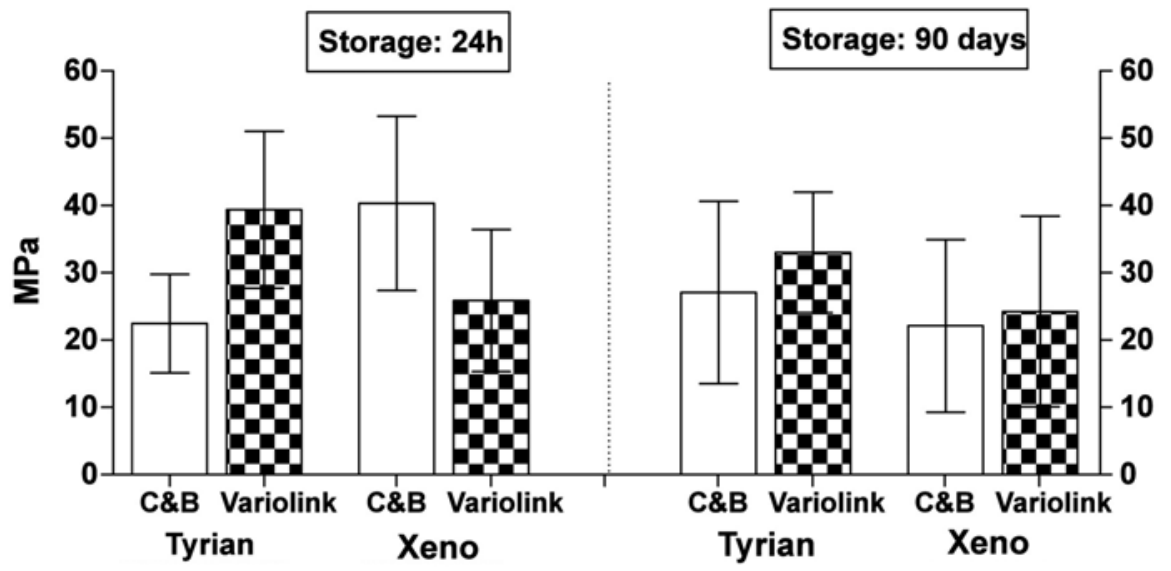

FIGURE 1- Graphic presentation of the $\mu$ TBS means \pm standard deviations (MPa) for the experimental groups

TABLE 2- Tukey's test intergroup differences of four adhesive/cement combinations, under two storage regimens and number of beams tested in each group

\begin{tabular}{|c|c|c|c|c|}
\hline Storage Time & Adhesive & Cement & Mean $\pm s d(\mathrm{MPa})$ & $\begin{array}{l}\text { Number of beams } \\
\text { stressed to failure }\end{array}$ \\
\hline \multirow[t]{4}{*}{$24 \mathrm{~h}$} & Tyrian SPE-One & $C \& B$ & $22.4 \pm 7.3^{C}$ & 28 \\
\hline & Step Plus & Variolink II & $39.3 \pm 11.6^{\mathrm{AB}}$ & 36 \\
\hline & Xeno III & $C \& B$ & $40.3 \pm 12.9^{A}$ & 84 \\
\hline & & Variolink II & $25.8 \pm 10.5^{c}$ & 80 \\
\hline \multirow[t]{4}{*}{90 days } & Tyrian SPE-One & $C \& B$ & $22.1 \pm 12.8^{\mathrm{C}}$ & 27 \\
\hline & Step Plus & Variolink II & $24.2 \pm 14.2^{\mathrm{C}}$ & 48 \\
\hline & Xeno III & $C \& B$ & $27.0 \pm 13.5^{c}$ & 80 \\
\hline & & Variolink II & $33.0 \pm 8.9^{\mathrm{B}}$ & 91 \\
\hline
\end{tabular}




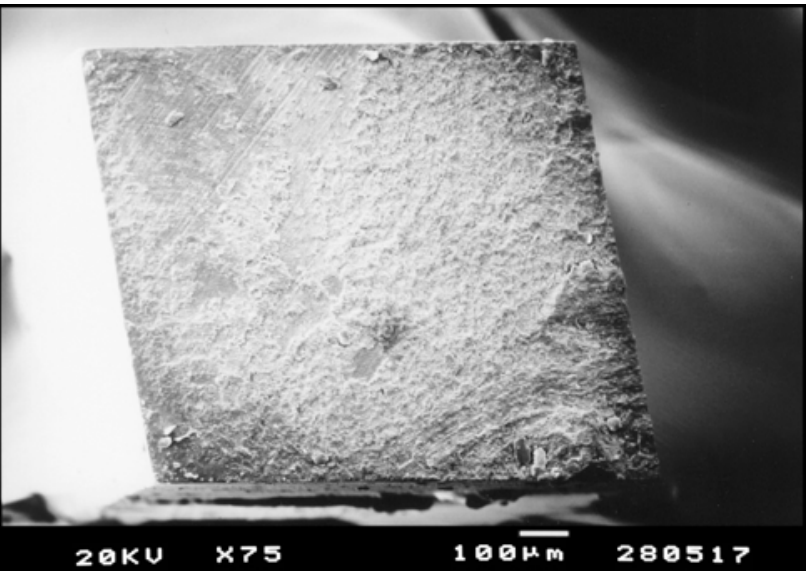

A

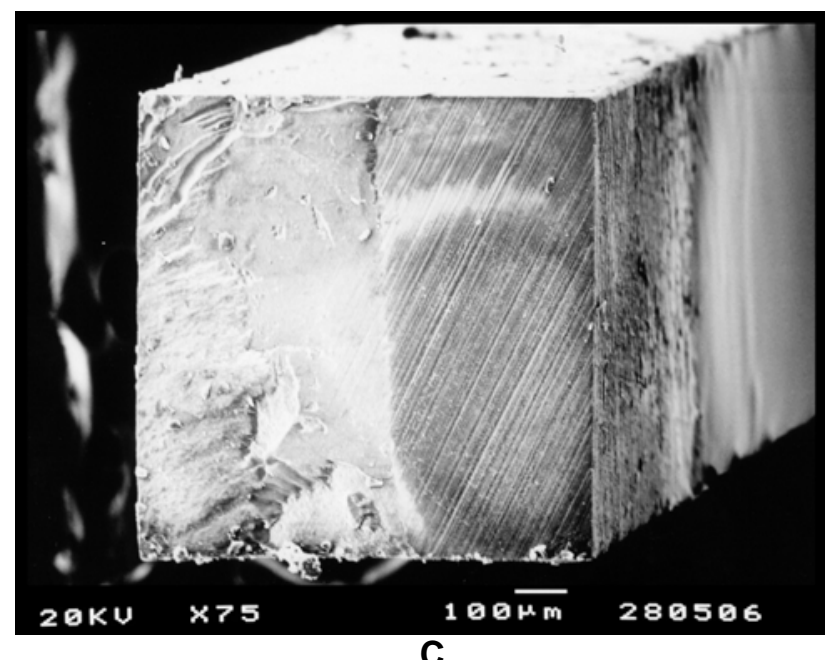

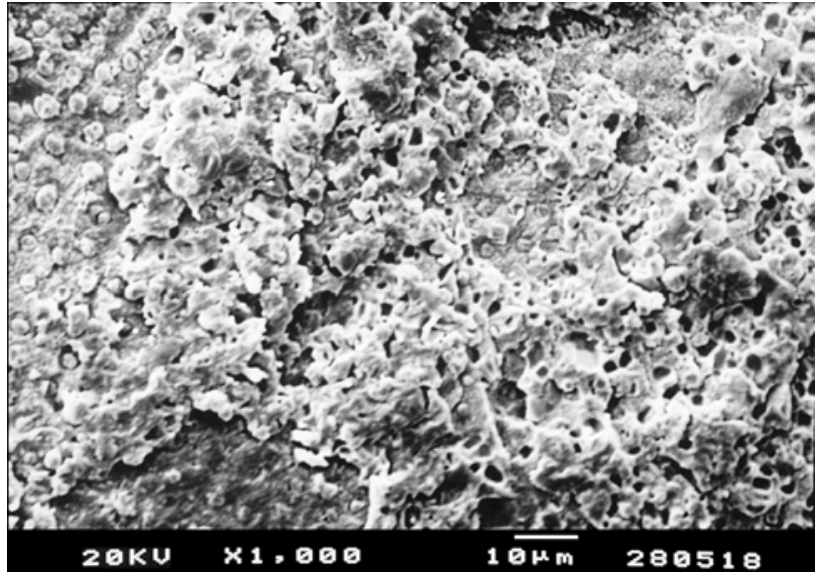

B

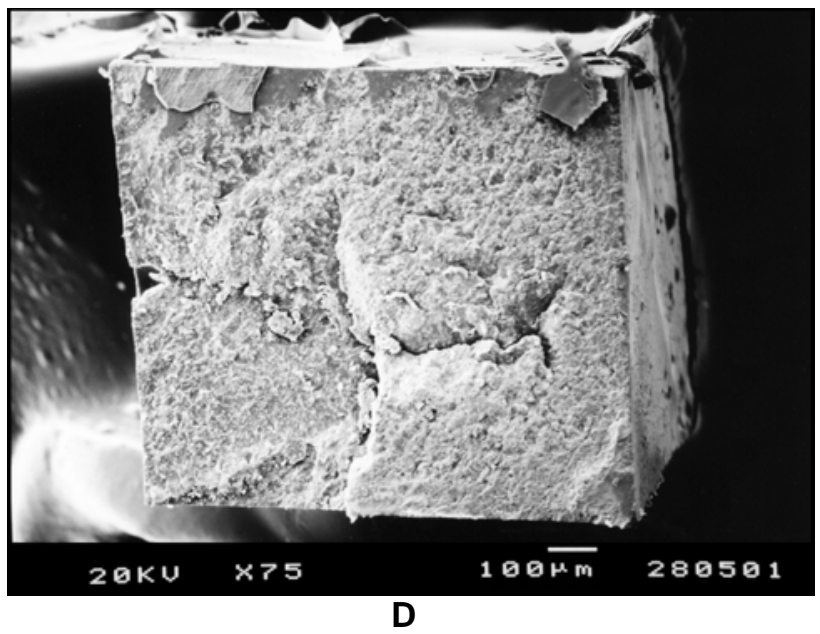

FIGURE 2- Dentin side of beams. (A) Tyrian SPE/One Step Plus/C\&B/24 h; (B) Tyrian SPE/One Step Plus/C\&B/24 h interface and cement remnants (c); (C) Tyrian SPE/One Step Plus/VariolinkII and (D) Xeno III and C\&B, after 90 days of storage

\section{RESULTS}

Three-way ANOVA showed statistically significant effects for the main factors as well as for the interaction between them $(\mathrm{p}<0.0001)$. Figure 1 shows that the relationship between the variables "cement" and "adhesive" after 24-h storage is not the same as the relationship observed after 90-day storage.

The interaction effect was evaluated by the Tukey's test $(\mathrm{p}<0.05)$ (Table 2). Tyirian/One Step Plus/Variolink II and Xeno III/C \& B presented the highest mean values at 24-h storage in water. Long-term storage decreased the $\mu$ TBS values of the Xeno III/C \& B group, whereas the combination of the same adhesive with Variolink II produced increased bond strengths over time. There was also a significant effect of the 90-day storage in water on the bonding durability of the groups Tyrian SPE/One Step Plus/Variolink II and Xeno III/C \& B.

The dentin halves of at least 2 fractured beams per group were examined with a scanning electron microscope. The fracture patterns occurred along the dentin/adhesive/cement interface. Most of the dentin sides of the beams were partially
(Figures 2A, 2B and 2C) or almost completely (Figure 2D) covered with resin cement.

\section{DISCUSSION}

Although many dentists have assumed that composites couple well with dentin adhesives, chemical incompatibility

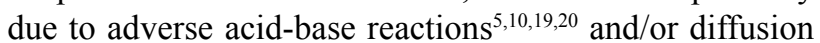
of water through the adhesive layer can damage bonding to dentin $^{6,21,22}$. In the present study, the bonding effectiveness of a light-activated cement with the application of a two- or an one-step self-etching adhesive was compared to that of a chemical resin cement used with the same adhesives.

A number of factors can affect bonding at the resin/ adhesive/dentin interface. such as the moisture degree ${ }^{6}$, bonding agent composition ${ }^{8}$, light intensity ${ }^{10,15}$, oxygen ${ }^{19,20}$, and so forth. However, there are also factors related to the luting agents that can affect bonding. As an example, in the present study, the lack of proper seating pressure during cementation might have contributed to non-standardized cement film thickness, influencing the bond strength 
results ${ }^{14,16}$

One should expect that the high acidity of Xeno III led to incomplete polymerization of the chemical luting cement and to low bond strengths, but this was not observed in the current study. Thus, the first null hypothesis was rejected because groups cemented with the same cement presented statistically significant differences. It was said previously that contemporary 'all-in-one' adhesives cannot compete with the more traditional multi-step adhesives. The reasons for that are not only the acidic components of these adhesives that may adversely interact with the photoinitiator system of the composite, but also the problems related to dentin bonding, which are: (1) their hydrophilicity, leading them to behave as semipermeable membranes; (2) their high solvent concentration, impairing the creation of a solventfree environment; (3) their susceptibility to phase separation and blistering due to changes in monomer/water ratio ${ }^{7}$. In fact, some studies have shown that the two-step self-etching adhesives provide superior bonding performance than allin-one systems ${ }^{1,5,11,18,19}$, whereas others ${ }^{4,12,17,25}$ have shown that, cured properly, self-etching adhesives such as Xeno III produce similar or higher bond strengths to dentin than 2-step systems.

The number of beams stressed to failure in the Tyrian SPE/One Step Plus groups was much smaller than that of the Xeno III groups, which reflects the number of premature failures that occurred in the former groups. Although SEM evaluation of all beams was not performed, it is speculated that Tyrian SPE/One Step Plus did not uniformly interact with dentin, as its mild $\mathrm{pH}$ might not have uniformly and completely exposed collagen for hybridization ${ }^{5,24}$.

At 90-day water storage, all groups had statistically similar bond strengths, except for Xeno III/ Variolink II, requiring rejection of the second null hypothesis. Furthermore, the better performance of Xeno III/ Variolink II and the worse performance of TyrianSPE/One Step Plus/ Variolink II and Xeno III/C \& B after water aging, resulted in statistically significant differences compared to their corresponding groups at 24-h storage. For that reason, the third null hypothesis that there are no differences in bonding durability between the 24-h and 90-day storage periods was also rejected.

It was not the scope of the present study to evaluate the luting agent/hard tissue interface ultramorphologically. However, it is well known that the performance of both adhesives and resin cements are definitely compromised by the effects of solvent uptake and hydrolytic degradation ${ }^{23}$. Water sorption can lead to swelling, plasticization and softening of the polymer network. The extent and rate of water uptake depends on the density of the polymer network and the potential for hydrogen bonding and polar interactions ${ }^{9}$. According to a previous study ${ }^{11}$, Xeno III showed substantially more early water uptake due to its high hydrophilicity, which correlated with significantly lower microtensile bond strength over time, whereas resins such as One Step Plus (which is used in conjuction with Tyrian SPE) were considered hydrophobic and capable of increasing the bond durability because they decrease the probability of nanoleakage within the hybrid layer ${ }^{2,11}$. Thus, regarding the worse performance of Tyrian SPE/One Step Plus/Variolink II after 90 days storage, it is possible that its ultra-thin hybrid layer was unable to withstand the exposure to water (Figure $1 \mathrm{C}$ ), rather than being damaged by permeability of the adhesive.

The resin cements used in the present study are very susceptible to water sorption and its consequences, since C $\&$ B is mainly composed of linear PMMA and Variolink II has only a small amount of difunctional methacrylate (BisGMA, TEGDMA, UDMA). This fact must have contributed to the occurrence of cohesive failures at the cement layer, as shown in Figure 1D.

Although Xeno III is not indicated for use with selfcure or dual-cure materials without light curing, it produced the highest bond strength means in the long-term evaluation, when the light-cured cement was employed. It is our belief that this may have been caused by increased polymerization over time. However, the question to what extent this may have influenced the bond strengths after 90 days of water storage cannot be answered based on the results of the present study. In addition, since only flat dentin surfaces were used, it is believed that stresses at the bonding interfaces were not a cause of the lower bond strengths observed in the present study. Thus, in vitro studies simulating the stress contraction that occurs in real cavity preparations are desirable.

Recently, Garcia, et al. ${ }^{12}$ evaluated the shear bond strengths between the bonding agents used in the present study and dentin and found that Tyrian SPE and Xeno III had the same performance after 7 days or 1 year of storage. Similarly, Sadek, et al. ${ }^{17}$ studied the performance of these adhesives bonded to human dentin and light-cured composite and found that the results were comparable after $24 \mathrm{~h}$. This raises the question of whether the two-step self-etching adhesives can be successfully associated with chemically cured or light-cured cements ${ }^{6}$ or, more specifically, whether Tyrian SPE can really provide better bonding when associated with such materials. In order to answer that question, perhaps the role of hydrophilic monomer/solvent combinations on the bonding durability of such materials needs to be addressed.

\section{CONCLUSION}

The bond strength to dentin depends on the luting agent/ adhesive employed. In the present study, Xeno III/Variolink II was the luting agent/adhesive combination that provided the most promising bond strength after 90 days of storage in water. 


\section{REFERENCES}

1- Bishara SE, Ajlouni R, Laffoon JF, Warren JJ. Comparison of shear bond strength of two self-etch primer/adhesive systems. Angle Orthod. 2006;76(1):123-6.

2- Carvalho RM, Pegoraro TA, Tay FR, Pegoraro LF, Silva NRFA, Pashley DH. Adhesive permeability affects coupling of resin cements that utilise self-etching primers to dentine. J Dent. 2004;32(1):55-65.

3- Caughman WF, Chan DCN, Rueggeberg FA. Curing potential of dual polymerizable resin cements in simulated clinical situations. J Prosthet Dent. 2001;85(5):479-84.

4- Chapman JL, Burgess JO, Holst S, Sadan A, Blatz MB. Precuring of self-etching bonding agents and its effect on bond strength of resin composite to dentin and enamel. Quintessence Int. 2007;38(8):637-41.

5- Cheong C, King NM, Pashley DH, Ferrari M, Toledano M, Tay FR. Incompatibility of self-etch adhesives with chemical/dual-cure composites: two-step vs one-step systems. Oper Dent. 2003;28(6):747-55.

6- Chersoni S, Suppa P, Breschi L, Ferrari M, Tay FR, Pashley DH, et al. Water movement in the hybrid layer after different dentin treatments. Dent Mater. 2004;20(9):796-803.

7- De Munck J, Van Landuyt K, Peumans M, Poitevin A, Lambrechts P, Braem M, et al. A critical review of the durability of adhesion to tooth tissue: methods and results. J Dent Res. 2005;84(2):118-32.

8- Ferrari M, Mannocci F, Vichi A, Cagidiaco MC. Bonding to root canal: Structural characteristics of the substrate. Am J Dent. 2000;13(5):25560

9- Ferracane J. Hygroscopic and hydrolytic effects in dental polymer networks. Dent Mater. 2006;22(8):211-22.

10- Foxton RM, Nakajima M, Tagami J, Miura H. Bonding of photo and dual cure adhesives to root canal dentin. Oper Dent. 2003;28(3):543-51.

11- Frankenberger R, Pashley DH, Reich SM, Lohbauer U, Petschelt A, Tay FR. Characterization of resin-dentine interfaces by compressive cyclic loading. Biomaterials. 2005;26(14):2043-52.

12- Garcia RN, Goes MF, Giannini M. Effect of water storage on bond strength of self-etching adhesives to dentin. J Contemp Dent Pract. 2007;18(7):46-53.

13- Hikita K, Van Meerbeek B, De Munck J, Ikeda T, Van Landuyt K, Maida $\mathrm{T}$, et al. Bonding effectiveness of adhesive luting agents to enamel and dentin. Dent Mater. 2007;23(1):71-80.

14- Molin MK, Karlsson SL, Kristiansen MS. Influence of film thickness on joint bend strength of a ceramic/resin composite joint. Dent Mater. $1996 ; 12(4): 245-9$.

15- Piwowarczyk A, Bender R, Ottl P, Lauer HC. Long-term bond between dual-polymerizing luting agents and human hard dental tissue. Dent Mater. 2007;23(2):211-7.

16- Prakki A, Cilli R, Da Costa AU, Gonçalves SE, Mondelli RF, Pereira JC. Effect of resin luting film thickness on fracture resistance of a ceramic cemented to dentin. J Prosthodont. 2007;16(3):172-8.

17- Sadek FT, Goracci C, Cardoso PE, Tay FR, Ferrari M. Microtensile bond strength of current dentin adhesives measured immediately and 24 $\mathrm{h}$ after application. J Adhes Dent. 2005;7(4):297-302.

18- Salz U, Zimmermann J, Zeuner F, Moszner N Hydrolytic stability of self-etching adhesive systems. J Adhes Dent. 2005;7(2):107-16.
19- Sanares AME, Itthagarun A, King NM, Tay FR, Pashley DH. Adverse surface interactions between one-bottle light-cured adhesives and chemical-cured composites. Dent Mater. 2001;17(6):542-56.

20- Suh BI, Feng L, Pashley DH, Tay FR. Factors contributing to the incompatibility between simplified -step adhesives and self-cured or dual cured composites. Part III. Effect of acidic resin monomers. J Adhes Dent. 2003;5(4):267-82

21- Tay FR, Suh BI, Pashley DH, Prati C, Chuang S, Li F. Factors contributing to the incompatibility between simplified -step adhesives and self-cured or dual cured composites. Part II. Single bottle, total etch adhesive. J Adhes Dent. 2003;5(2):91-105.

22- Tay FR, Pashley DH, Garcia-Godoy F, Yiu CK. Single-step, self-etch adhesives behave as permeable membranes after polymerization. Part II. Silver tracer penetration evidence. Am J Dent. 2004;17(5):315-22.

23- Toledano M, Osorio R, Ceballos L, Fuentes MV, Fernandes CA, Tay FR, et al. Microtensile bond strength of several adhesive systems to different dentin depths. Am J Dent. 2003;16(5):292-8.

24- Van Landuyt KL, Snauwaert J, De Munck J, Peumans M, Yoshida Y, Poitevin A, et al. Systematic review of the chemical composition of contemporary dental adhesives. Biomaterials. 2007;28(26):3757-85.

25- Yesilyurt C, Bulucu B. Bond strenght of total-etch dentin adhesive systems on peripheral and central dentinal tissue: a microtensile bond strength test. J Contemp Dent Pract. 2006;7(2):26-36. 